\title{
Quaternary lacustrine braid deltas on Lake General Carrera in southern Chile
}

\author{
C. Mike Bell
}

University of Gloucestershire, Francis Close Hall, Swindon Road, Cheltenham, Gloucestershire, United Kingdom. Correspondence address: 5 Blackthorn End, Leckhampton Lanes, Cheltenham, GL53 0QB, United Kingdom.

mikeandgillbell@btinternet.com

\begin{abstract}
A series of Quaternary lacustrine braid deltas on the shores of Lake General Carrera in southern Chile formed as a result of falls in lake level. Each delta comprises two components, the delta fan and the beach embayment, each in turn comprising an onshore subaerial and an offshore subaqueous element. The delta fans have a classic Gilbert form with a braided delta top and a steeply inclined delta front. Adjacent to the fans are concave beach embayments that formed parallel with the deltas as they prograded into the lake. The delta sediments consist predominantly of matrix- and clast-supported gravels to a total composite thickness exceeding $400 \mathrm{~m}$. The depositional environments are dominated by ephemeral river flooding and by storm-driven waves. Beach sediment is sorted, rounded, winnowed and transported alongshore by waves to fill the beach embayment with ridges of very well sorted and well-rounded gravel. A gentlydipping shoreface platform occurs up to $100 \mathrm{~m}$ offshore between the beach and the brink point. From the brink point, in water depth of about $8 \mathrm{~m}$, sediment cascades down the steep delta front slope to form long foresets extending to the lake floor. The sedimentary successions therefore wedge in the opposite direction from those of tectonically controlled basin margins where fan growth keeps pace with basin subsidence.
\end{abstract}

Keywords: Lacustrine braid deltas, Sedimentary environments, Sedimentary facies, Chile.

RESUMEN. Deltas entrelazados lacustres del Cuaternario en el lago General Carrera, sur de Chile. Una serie de deltas entrelazados lacustres, pertenecientes al Cuaternario, ubicados en las costas del lago General Carrera, en el sur de Chile, se formaron como resultado de caídas en el nivel del lago. Cada delta consta de dos componentes: el abanico deltaico y la zona de embahiamiento. Cada uno de ellos tiene, a su vez, un elemento subaéreo costero y un elemento subacuático. Los abanicos deltaicos tienen una forma Gilbert clásica con una parte superior de ríos entrelazados y un frente deltaico empinado. Adyacente a los abanicos aluviales existen bahías cóncavas de playa que se formaron de manera paralela a los deltas a medida que estos progradaron hacia el lago. Los sedimentos deltaicos consisten predominantemente de gravas matriz y clastosoportadas con un grosor total compuesto que excede los $400 \mathrm{~m}$. Los ambientes depositacionales están dominados por inundaciones efímeras del río y por olas de tormenta. Los sedimentos de playa están seleccionados, redondeados y fueron transportados a lo largo de la costa por las olas para rellenar el embahiamiento de la playa con dorsales de gravas muy bien clasificadas y redondeadas. Una plataforma del 'shoreface' de baja pendiente ocurre hasta $100 \mathrm{~m}$ agua adentro, entre la orilla y el borde. Desde el borde del lago, en el agua hasta los $8 \mathrm{~m}$ de profundidad, el sedimento cae en cascadas por la empinada pendiente del frente deltaico para formar grandes 'foresets' que se extienden hacia el fondo del lago. La sucesión sedimentaria se acuña, en consecuencia, en una dirección opuesta a la de aquella, de márgenes de cuenca controlados tectónicamente ('brink point'), donde el crecimiento de los abanicos mantiene un equilibrio con la subsidencia de la cuenca.

Palabras claves: Deltas entrelazados lacustres, Ambientes sedimentarios, Facies sedimentarias, Chile. 


\section{Introduction}

A chain of pro-glacial lakes fringes the eastern side of the southern Andes Mountains in Chile between 39 and $52^{\circ} \mathrm{S}$. The largest, known as Lake (Lago) General Carrera in Chile and Lake Buenos Aires in Argentina (Fig. 1), is $150 \mathrm{~km}$ long and 10 to $20 \mathrm{~km}$ wide. It is the third largest lake in South America (with an area of $1,900 \mathrm{~km}^{2}$ ) and one of the deepest on the continent with a depth of about $600 \mathrm{~m}$.

The lower sections of the Las Dunas and Los Maitenes rivers on the south-eastern shores of the western end of the lake are distinguished by a remarkable series of seven superimposed lacustrine deltas (Figs. 2, 3, 4 and 5). These deltas formed as the lake level partly drained from $650 \mathrm{~m}$ to $201 \mathrm{~m}$ above sea level in a punctuated sequence of events over the past 13,000 years (Bell, 2008). The deltas form a series of flat-topped steps extending inland from the present lake (Niemeyer et al., 1984; De la Cruz and Suárez, 2006) (Figs. 2 to 7). The presentday active delta is numbered one on the figures, with progressively older abandoned deltas numbered from two to seven.

Themodern sediments provide a good exemplar for similar deposits in the geological record because there has been little human impact in this remote area.

The present study, which emphasises the morphology and sedimentology of the Las Dunas River deltas, was undertaken during 10 weeks of field work. Field observations were supplemented by the study of aerial photographs taken in 1970 by the Fuerza Aeréa and topographic maps of the Instituto Geográfico Militar of Chile.

\section{Lacustrine Fan Deltas}

The lacustrine deltas of Lake General Carrera have features characteristic of both fan-deltas and braid deltas. Fan-deltas form where alluvial fans prograde directly into standing water from adjacent highlands; and lacustrine braid deltas are fan-shaped bodies of coarse-grained sediment produced by the progradation of braided fluvial systems (Bowman, 1990; Hampton and Horton, 2007; Horton and Schmitt, 1996; McPherson et al., 1987, 1988; Nemec et al., 1984; Nemec and Steel, 1988; Ricketts and Evenchick, 2007). Braid-deltas are non-tidal, but their geographical and sedimentary characteristics resemble those of marine fan deltas (Bornhold and Prior, 1990; Corner et al., 1990; Ethridge and
Wescott, 1984). The deltas on Lake General Carrera bear a close resemblance to those of Lake Bonneville, Utah, USA (Gilbert, 1890; Lemons and Chan, 1999; Oviatt et al., 1994).

\section{Geomorphology of Lake General Carrera and surrounding areas}

During Pleistocene times the massive Patagonian Icefield blanketed the southern Andes (Clapperton, 1993; Heusser, 2003; Hulton et al., 1994). Glaciers scoured out deep valleys as they flowed eastwards from the icefield towards the Atlantic Ocean. Lake General Carrera occupies one of these glacial valleys. It is surrounded to the west by 4,000 $\mathrm{m}$ high mountains capped by the shrunken remnants of the icefield (Fig. 1). The lake broadens out and shallows on the Patagonian plains towards the east in Argentina, where it is rimmed by arcuate terminal and recessional moraines, dated at between 760,000 and 16,000 years BP (Kaplan et al., 2005). The lake is drained towards the south-west in Chile by the Baker River as it flows through a deep gorge through the Andes Mountains and into the Pacific Ocean. Before the opening of this gap through the mountains a much larger ice-dammed lake named the predecessor lake (Bell, 2008) drained eastwards via the Deseado River into the Atlantic Ocean.

About 13,000 years ago the ice dam at the western end of the predecessor lake melted (Glasser et al., 2004) and produced punctuated drops in the lake level recorded by the fans of the present study (Figs. 2 and 3) (Bell, 2008).

The timing, nature and sequence of Quaternary events in this little-studied region are poorly constrained and understood (Bell, 2008). Deltas six and seven probably formed about 13,000 years ago. Delta number two had built out into the lake by $8.5 \pm 0.7 \mathrm{ka} B P$ and possibly as long ago as $12.2 \pm 1.5$ $\mathrm{ka}$ BP. The drop in lake level leading to the formation of delta number one occurred after $6.2 \pm 0.8 \mathrm{ka}$ BP (Bell, 2008).

\section{Geographical and sedimentary features of the deltas}

The Las Dunas River is about $30 \mathrm{~km}$ long, with a steep profile exceeding $25 \mathrm{~m} \mathrm{~km}^{-1}$ in its lower sections. Numerous short tributaries feed the deeply-incised valley. The river descends from 2,250 m in mountains which have lower slopes blanketed in 


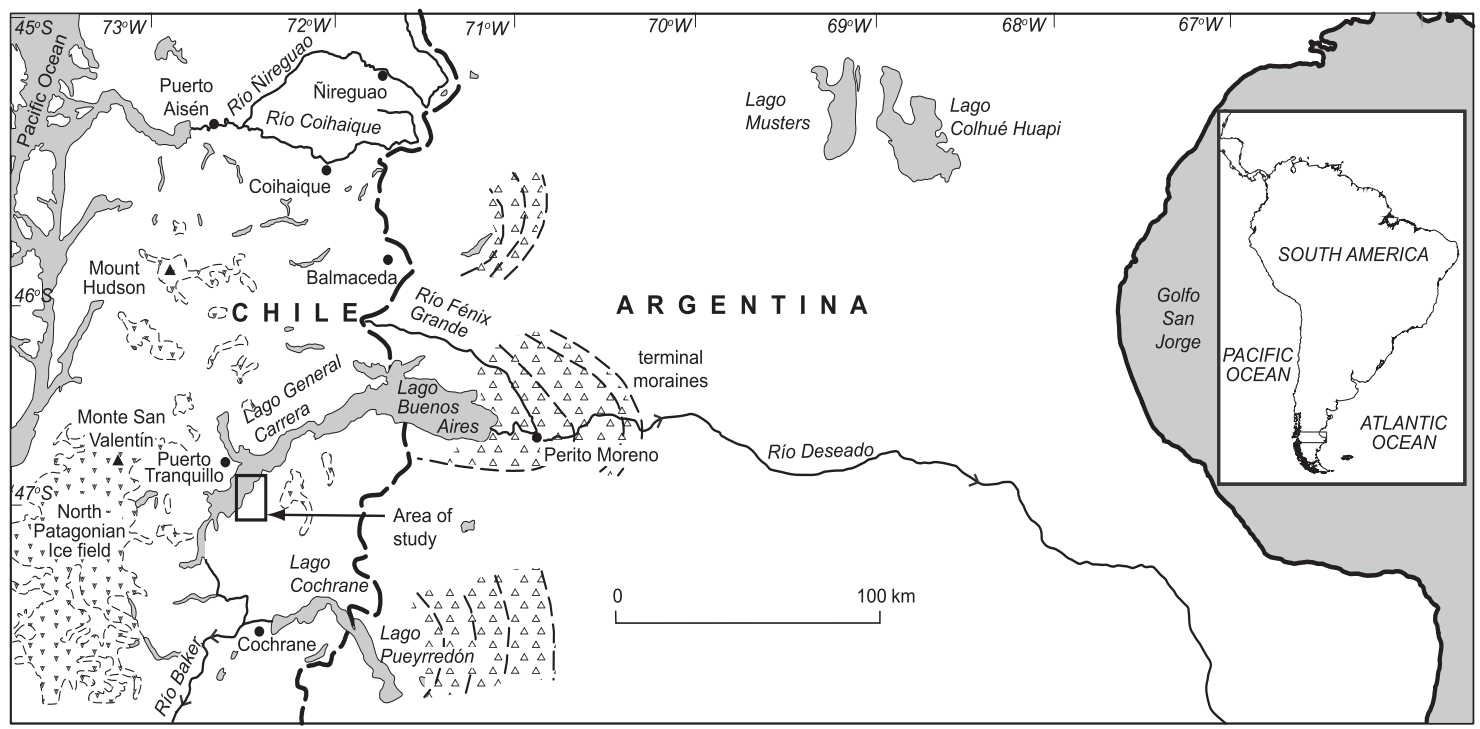

FIG. 1. Location map showing the study area on the southeast shores of Lake General Carrera. To the west of the lake are the Andes Mountains and the North Patagonian Icefield. To the east are terminal moraines and the Argentine plains.

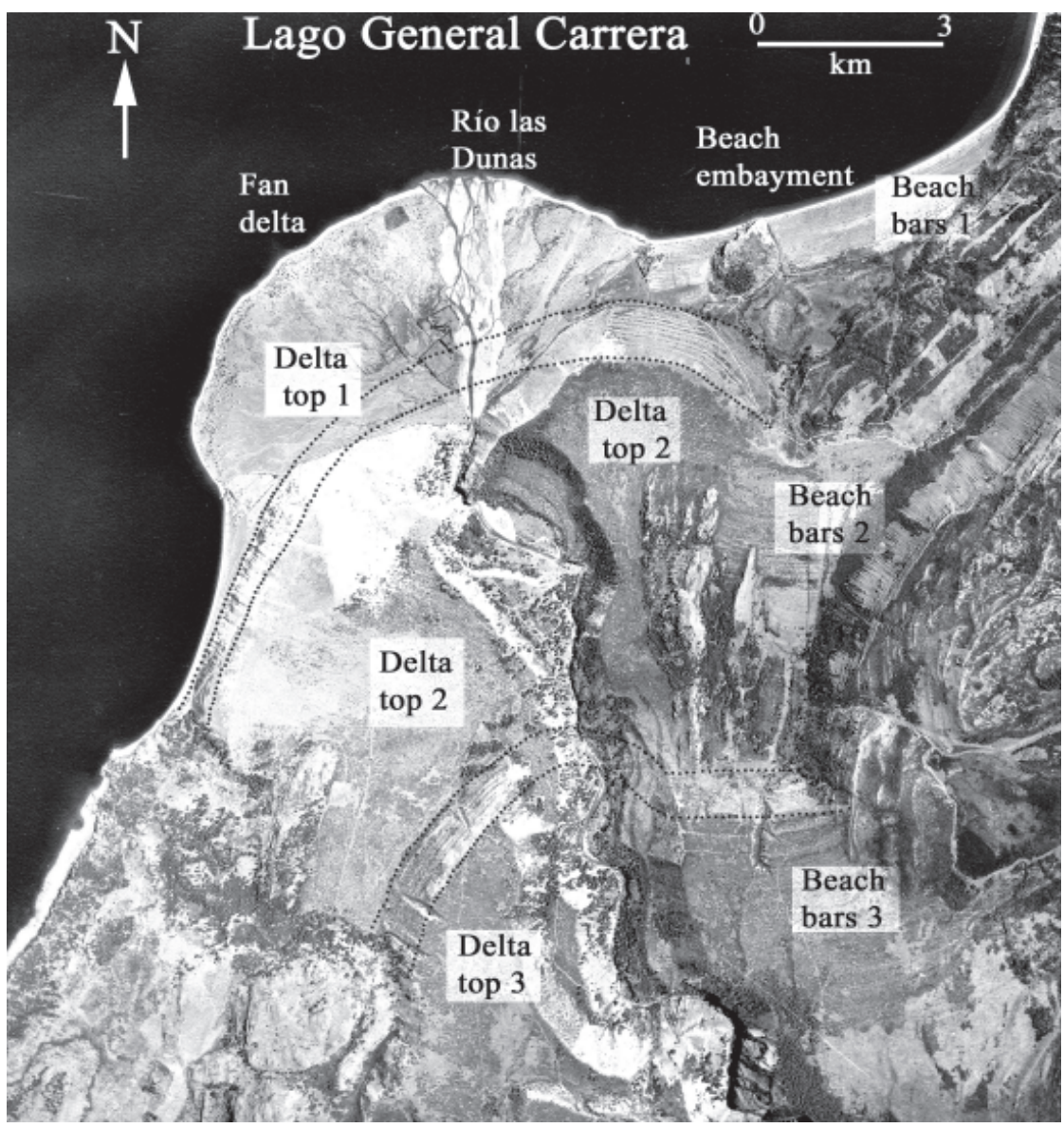

FIG. 2. Vertical aerial photograph CY01261 taken in 1970 by the Fuerza Aérea de Chile showing lacustrine deltas of the Las Dunas River. The active fan with its adjacent flanking beach embayments are backed by the flat-topped abandoned deltas 2 and 3 . 


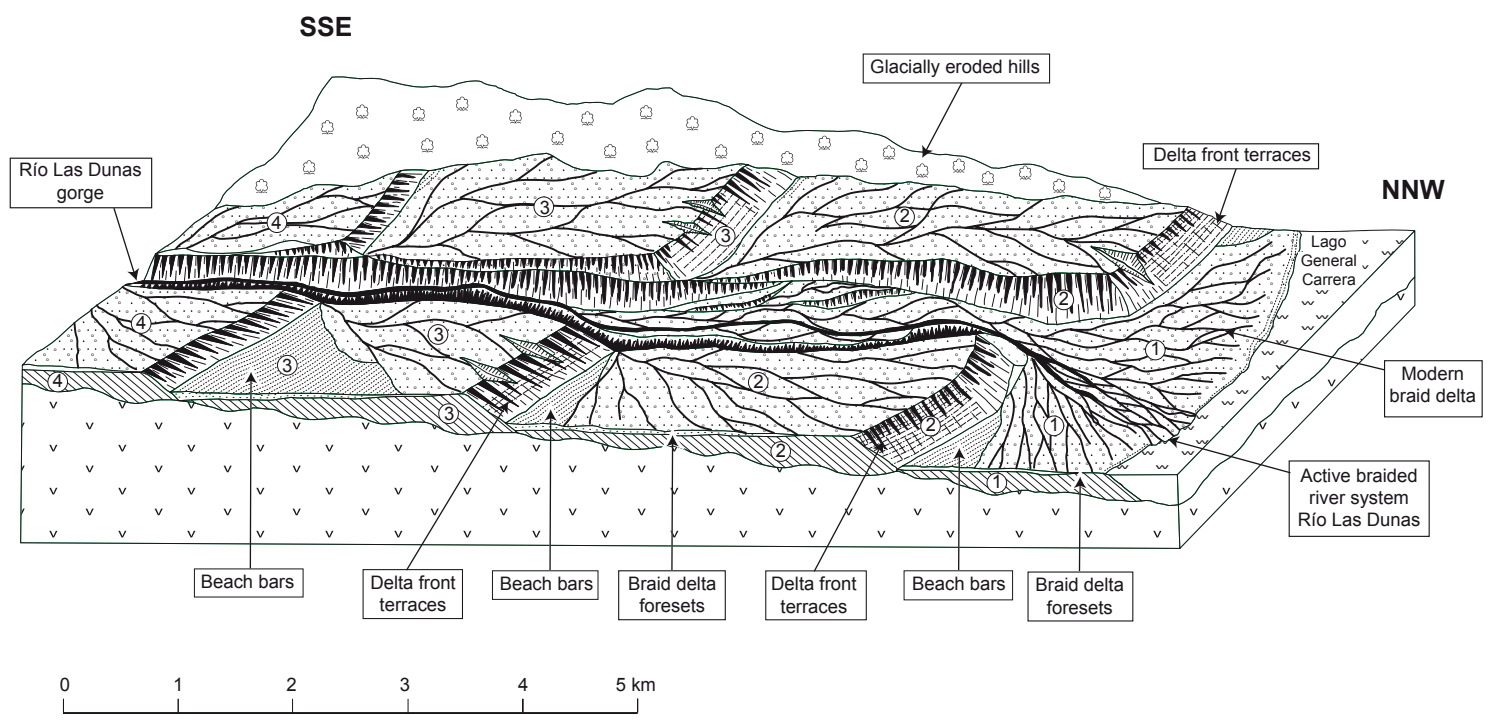

FIG. 3. Block diagram of the lacustrine deltas of the Las Dunas River based on aerial photographs taken in 1970 by the Fuerza Aérea de Chile.

a dense vegetation of trees, bushes, grass and moss. Rocky screes cover the mountain sides above a sharply-defined tree line at about $1,250 \mathrm{~m}$. The present-day river catchment has small permanent snow and ice patches but no active glaciers. During normal flow the clear waters transport little sediment, but periodic floods produced by storms and spring snow melt, transport heavy loads of predominantly coarse-grained sediment. There is no recorded data on the frequency or intensity of these floods or the sediment flux. Likewise there is no published record of local weather conditions. The region is very stormy, with frequent high winds, predominantly from the west. Precipitation in the form of rain and snow is high. Seasonal and storm-driven fluctuations in the lake level are about two metres.

The descriptions of McPherson et al. (1987) emphasised the morphology and sedimentology of the subaerial component of deltas. However, estimates of sediment volume on the Lake General Carrera deltas suggest that an overemphasis on the subaerial section is likely to be misleading in interpreting the geological record. Although the braided fan surface is the most obvious morphological feature, forming two thirds of the subaerial exposures, its deposits comprise less than $20 \%$ of the sediment volume of the delta complex. More significant in terms of volume are the deposits of the beach, the offshore shoreface platform and in particular the foresets of the delta front, which together comprise about $70 \%$ of the total. Deposits transported alongshore by oblique waves into the beach embayments in the lee of the fan form a further element of about $10 \%$ of the total sediment volume.

\section{Morphology and sediments of the deltas}

The deltas are characterised by two main environments, each with a distinctive morphology, sedimentary facies or facies assemblage and depositional processes. Each environment has a subaerial and a subaqueous element, separated by a beach. The first of the main environments is the semi-circular delta fan, traversed by a radiating pattern of braided river channels (Figs. 2, 3 and 9 ). These fans are convex towards the lake with a semi-circular shape and a radius of between one and two kilometres.

The composite sediment thickness of the seven superimposed deltas of the Las Dunas River exceeds $400 \mathrm{~m}$ (Fig. 3), with the steeply-dipping front of each of the larger deltas more than $100 \mathrm{~m}$ in height. The deltas are classified as type-A shallowwater classic Gilbert-type deltas in the scheme of Postma (1990) with characteristic features of flattops, a fan-shape and steep fronts.

The second environment is the beach embayment, gently concave towards the lake and backed 


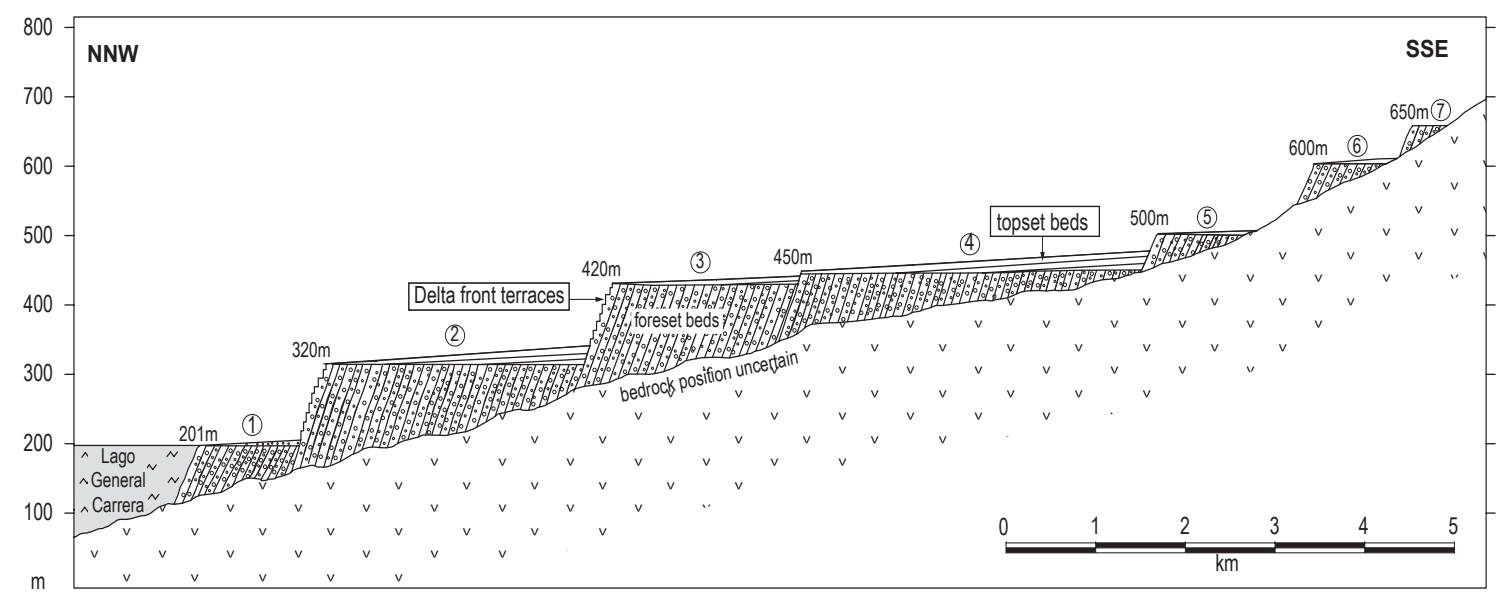

FIG. 4. Cross section diagram of the deltas of the Las Dunas River.

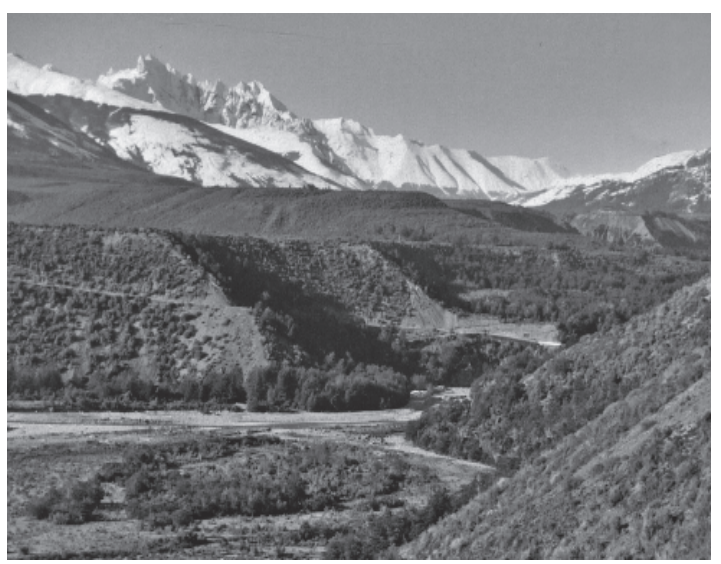

FIG. 5. Deltas of the Los Maitenes River. Apex of delta 1 in left foreground. Delta 2 forms the flat-topped plain in the centre left.

by a gently sloping plain characterised by semicontinuous gravel ridges, in the lee on either side of the fan (Figs. 2, 8 and 9).

The present-day active delta fan environment can be subdivided into subaerial onshore and subaqueous offshore components, separated by a beach (Figs. 9 and 10). The subaerial component is the gently sloping delta plain or delta top, characterised by a fan of braided channels with active and inactive tracts. No underwater observations were made during the present study but the observations of Rojas and Le Roux (2005) suggest that the subaqueous component has a shallow portion, the shoreface plat-form, sloping at about $6^{\circ}$, and extending up to

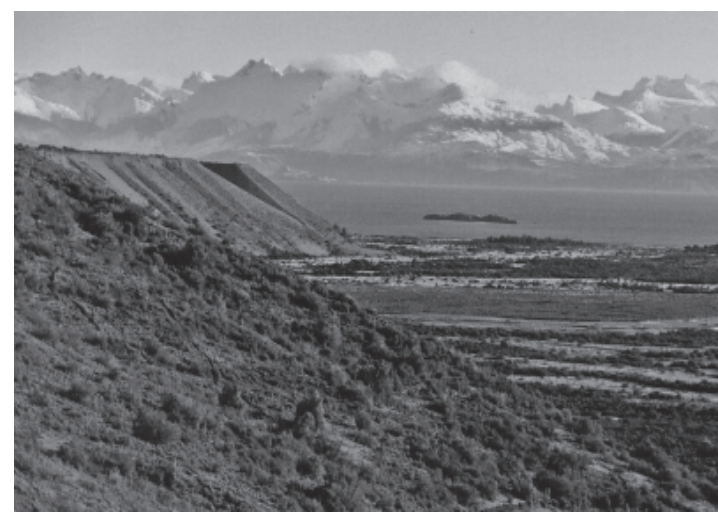

FIG. 6. Delta fan of the active delta of the Las Dunas River in the right foreground. The flat delta top and sloping delta front of delta 2 on the left. Lake General Carrera and the Andes Mountains in the background.

$100 \mathrm{~m}$ offshore. Observations on the abandoned deltas of the present study indicate that the steeper delta front or Gilbert foreset slope is inclined at about $30^{\circ}$ and extended to a water depth of about $100 \mathrm{~m}$.

The beach environment has an onshore section of a ridged gravel plain of abandoned beach bars (Fig. 8) and a presumed offshore section of a shoreface platform and delta front with a morphology similar to that of the delta fan.

The grain size of the clastic debris of the deltas varies from boulders to clay, with a great predominance of coarse-grained material. The composition of the sediment on the delta top, reflecting the rocks in the provenance, is $70 \%$ Mesozoic felsic volca- 


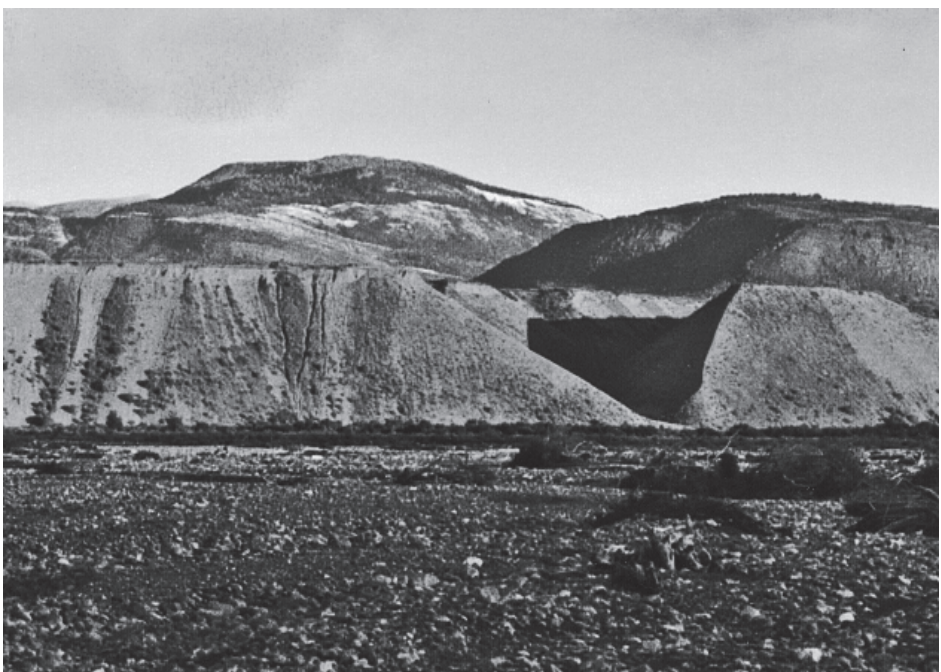

FIG. 7. Steeply-sloping delta front and flat top of abandoned delta 2 cut by an erosive valley. Braided top of delta 1 in the foreground.
FIG. 8. Fan of delta 1 jutting into the lake with the beach embayment and beach bars in the foreground The flat top and steeplyinclined delta front slope of delta 2 in centre left.

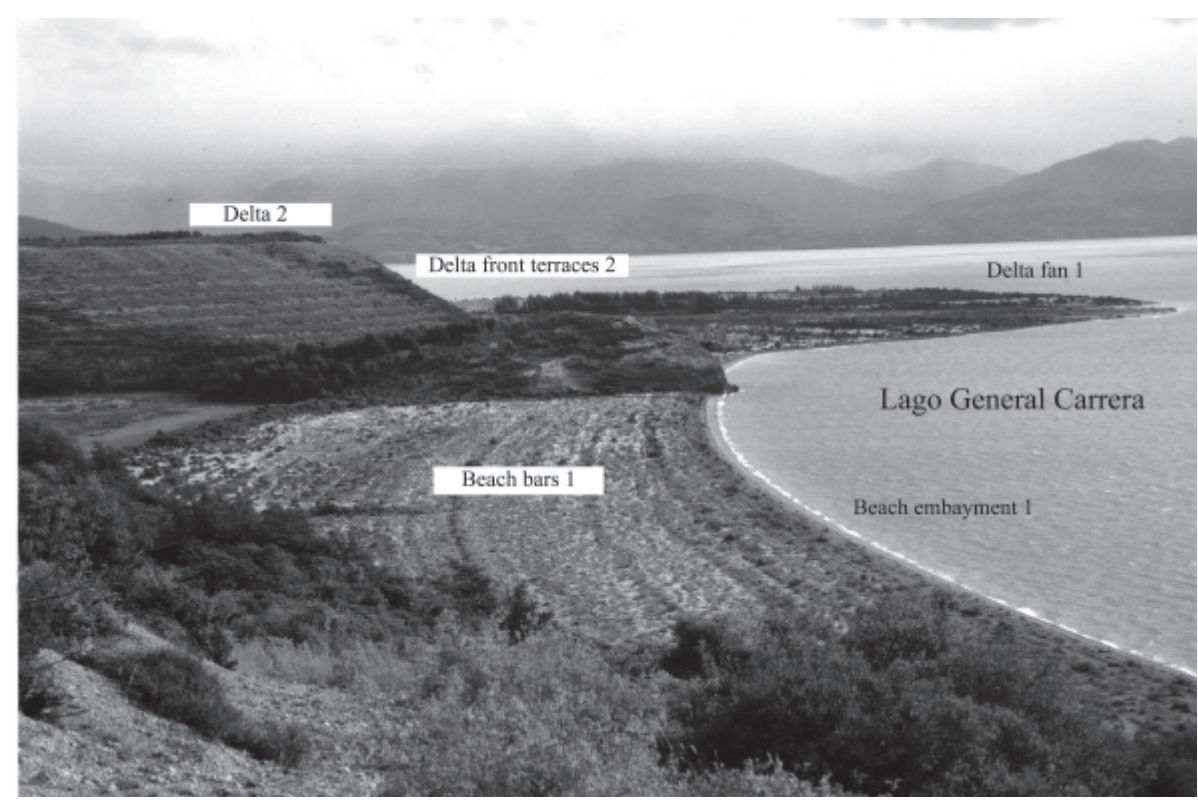

nics, 20\% Palaeozoic quartz mica schist and vein quartz, and 10\% Tertiary marine sandstone (Bell and Suárez, 2000). The abrasive effect of wave reworking means that the proportion of the harder quartz-rich schist and vein quartz increases to about $50 \%$ in the beach gravels.

\section{Subaerial onshore section of the delta fan}

The flat delta fan top surfaces dip gently towards the lake with a regular gradient of less than $1^{\circ}$; a drop of about ten metres in each kilometre. The presentday fan of the Las Dunas River has a radius of 1.3 $\mathrm{km}$ and covers an area of about $2.5 \mathrm{~km}^{2}$. The fan has a single point of input, controlled by outcrops of basement rocks. Periodic avulsion of the braided river (probably on a time scale of hundreds of years) near the point of input has produced an overlapping sequence of active and inactive tracts fanning out across the delta. The active tract of the present-day fan, indicated on aerial photographs by an absence of vegetation (Fig. 2), is 250 to $500 \mathrm{~m}$ wide and 


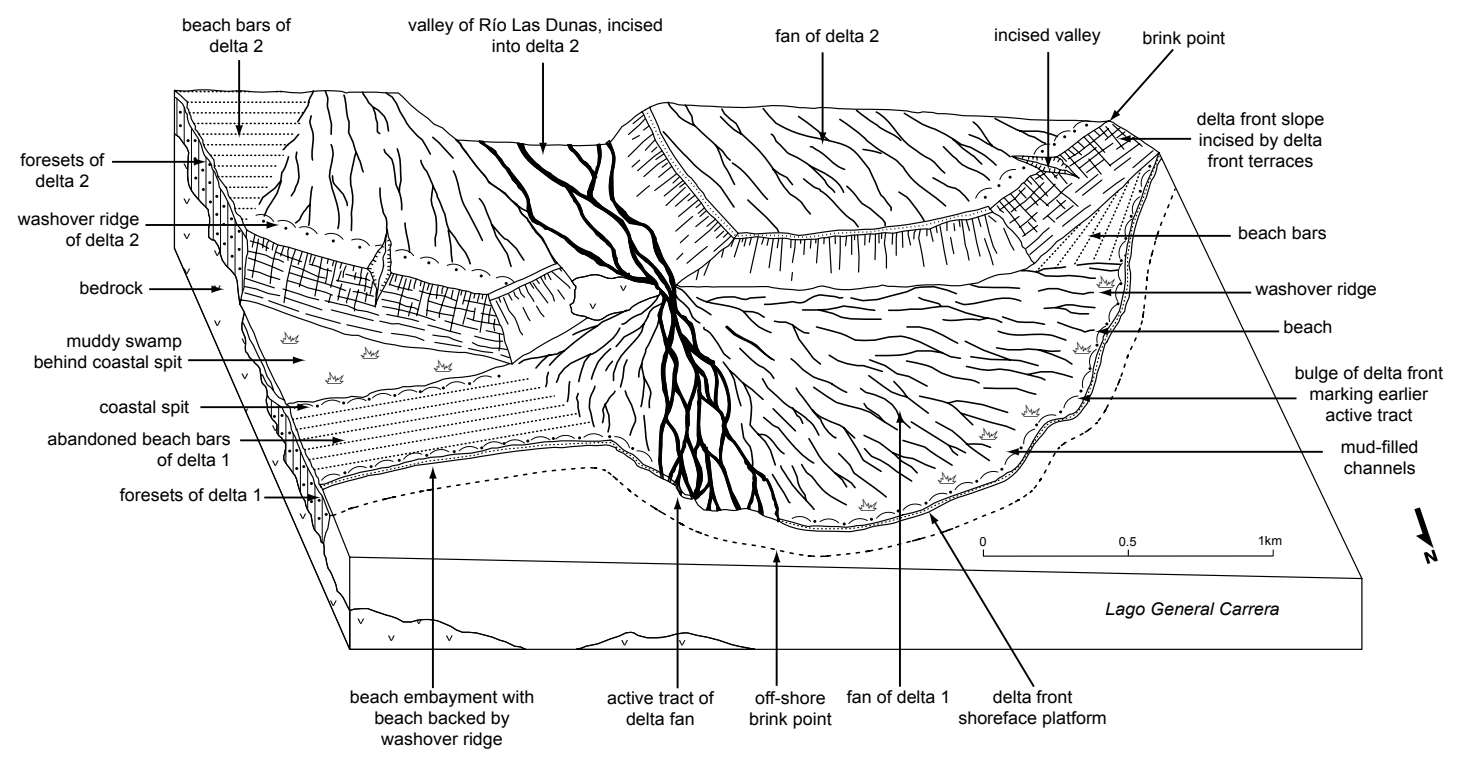

FIG. 9. Diagram showing the nomenclature of the morphological components of deltas 1 and 2.

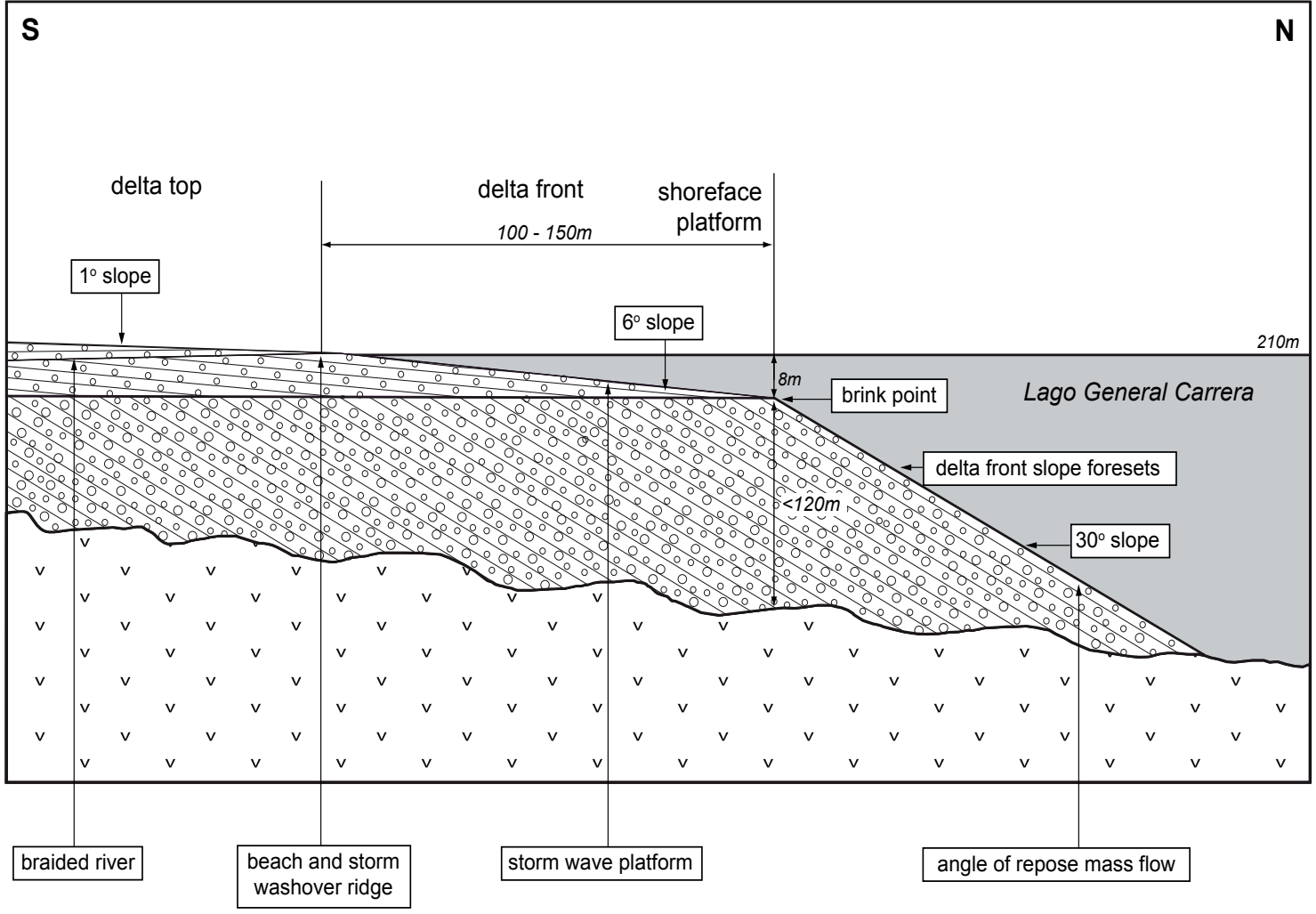

FIG. 10. Cross-section of an active delta fan showing the subaerial delta top and the subaqueous delta front that is subdivided into the shoreface platform and the delta front slope. 
occupies about one eighth of the fan surface. The braided channels are a few metres wide, weaving between low elongated diamond-shaped bars up to several hundred metres long (Fig. 11). The poorly sorted, well-rounded to subangular sediment ranges from cobbles (up to $200 \mathrm{~mm}$ ) to coarse sand. Finer material is deposited in pools and cut off channels during periods of low river flow. Over-bank splays of coarse sediment form fan-shaped deposits alongside the active tract during flood events (Fig. 12). Where the active tract reaches the lake it forms a bulge protruding about $150 \mathrm{~m}$ into the lake (Fig. 13). The river mouth is characterised by islands and narrow beaches of gravel and coarse sand.

The outer edge of the inactive sections of the present-day subaerial fan is fringed by a $10 \mathrm{~m}$ wide gently sloping beach (Fig. 14) comprising well to

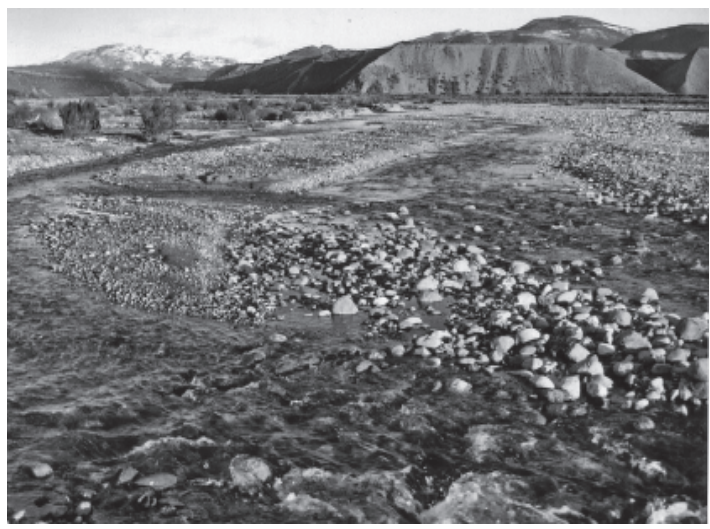

FIG. 11. Braided channels and bars of the delta top during normal river flow.

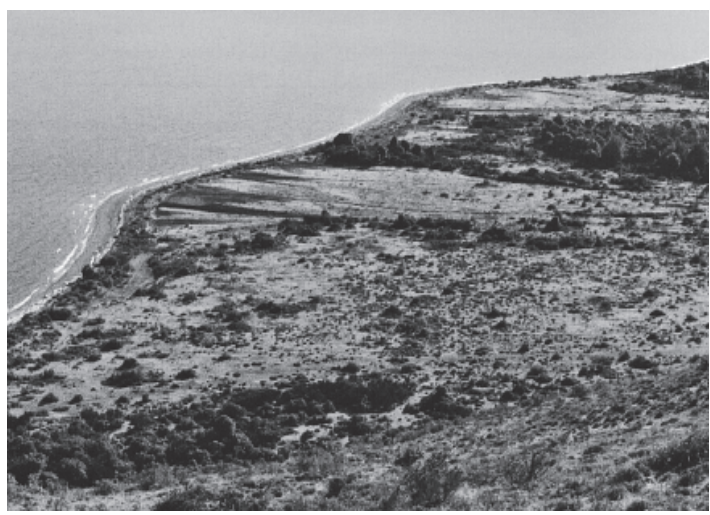

FIG. 13. Bulges of the delta fan front. Dark-coloured vegetation marks the wash-over ridge behind the beach and swamps in abandoned channels. poorly sorted gravel and coarse sand. The lower part of the beach, where waves break during normal weather conditions, is armoured with a $5 \mathrm{~m}$ wide lag of well-sorted and tightly-packed cobbles. Inland from the beach there is a broad, ridge of gravel, 1 to $2 \mathrm{~m}$ high, and coarse sand, picked out on air photographs by dark-coloured vegetation (Fig. 13). Inland from this ridge there are shallow muddy vegetated swamps. Similar fine-grained sediments fill the one to two metre deep abandoned braided channels on the fan surface.

\section{Subaqueous offshore section of the delta fans}

The subaqueous offshore morphology of the active deltas is illustrated diagrammatically in figure 10. No underwater observations were made

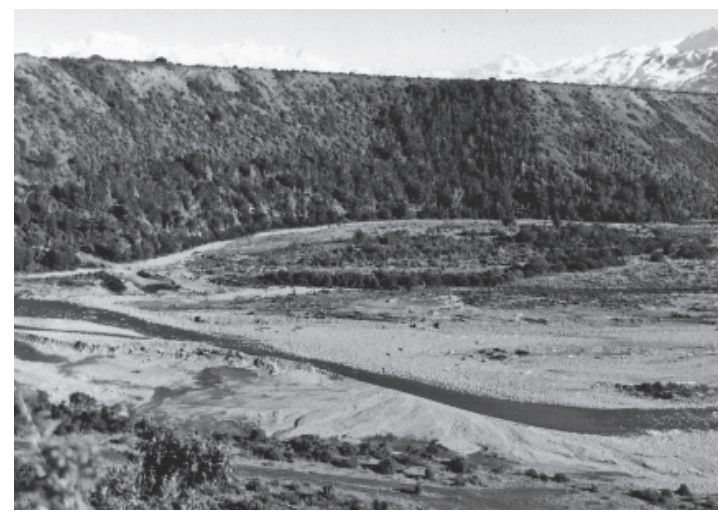

FIG. 12. Channel with overbank splays near the apex of the active delta fan. Delta 2 forms the flat-topped vegetated ridge beyond the river.

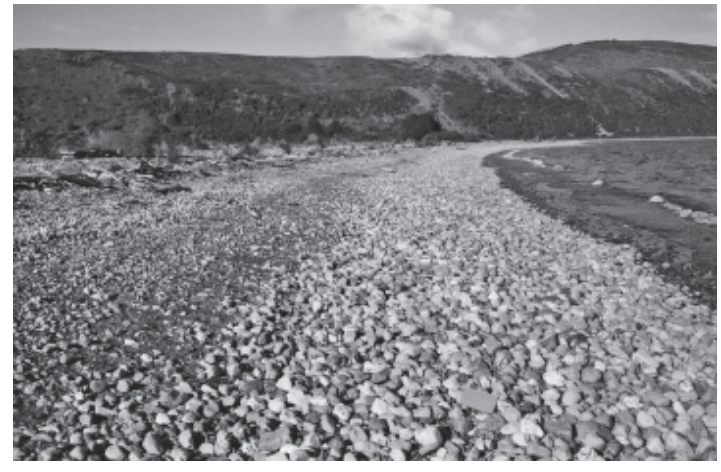

FIG. 14. Beach on the delta fan front armoured with a lag of wave-winnowed gravel. A storm wash-over ridge is inland from the beach. 
during the present study, but the abandoned deltas provided evidence of the subaqueous sediments, environments and processes. Further evidence of underwater development was inferred by comparison with studies of a similar delta on lake Llanquihue in southern Chile by Rojas and Le Roux (2005).

In the deltas of lake Llanquihue, extending about $100 \mathrm{~m}$ offshore and to a depth of about $8 \mathrm{~m}$, is a gentle slope with a maximum inclination of about $6^{\circ}$ (Rojas and Le Roux, 2005), called here the delta front shoreface platform. The surface exhibits both shallow erosion channels and depositional bars; sediments are matrix and clast-supported gravels, gravely sand and coarse sand, colonised by algae and gastropods (Rojas and Le Roux, 2005). Observations of the abandoned deltas of the present study indicate that the shoreface platform is sharply terminated by the delta front brink point, a well-defined and sharp boundary marking the top of the steep delta front slope (Fig. 18). The delta front slope of about $30^{\circ}$ (measured on abandoned deltas of the present study) forming the foresets of the Gilbert delta, is the angle of repose of gravel and coarse sand.

\section{Beach embayments}

Gravel beaches up to $2 \mathrm{~km}$ long backed by gravel plains fringe the embayments on either side of the delta fans (Figs. 8 and 15). Similar beach embayments, gently concave towards the lake, are characteristic of other lacustrine deltas in this region (Gilli et al., 2005). Bowman (1990) and Klinger et al. (2003) illustrated comparable beaches alongside lacustrine fan deltas of the Dead Sea. However, detailed descriptions of the morphology and sediments of these beach embayments have apparently not previously been published.

The embayments are larger on the eastern, downwind or lee side of both the present-day and abandoned deltas (Figs. 2 and 9). The present-day beaches form the front of gravel plains that extend inland for about $1 \mathrm{~km}$ (Fig. 8). The innermost section of the beach embayment east of the delta fan of the Las Dunas River is a vegetated muddy swamp formed behind a spit during early stages of development of the fan delta. The ridged gravel plain filling the beach embayment in front of the spit consists of a series of parallel one-metre high beach or swash bars (Renaut and Owen, 1991) spaced 10 to $25 \mathrm{~m}$ apart (Figs. 8 and 9).
The $10 \mathrm{~m}$ wide beach at the lake shore of the beach embayment is marked by very continuous small, low ridges of gravel, 1 to $2 \mathrm{~m}$ apart and rising in a series of steps to a height of about $2 \mathrm{~m}$ (Fig. 15). The ridges are asymmetrical, with a beach face sloping at $30^{\circ}$, near the angle of repose of the sediment, and a landward-dipping backshore berm with a slope of between 2 and $10^{\circ}$. Behind and above the beach there are $1 \mathrm{~m}$ high wash-over bars.

\section{Sedimentary facies}

The sedimentary facies of the Las Dunas River lacustrine deltas form a distinctive assemblage, characterised by coarse-grained clastic material (Fig. 16). Facies 1 and 2 are gravel-dominated successions characterised by poor-sorting. Facies 1 is cross-bedded with abundant channels (Fig. 17) whereas Facies 2 features long, straight and parallel bedded foresets (Fig. 18). Facies 3 comprises well-sorted beach gravels. Mudstones of Facies 4 form a very minor component of the total sediment volume. No measured section were made during the present study due to the unconsolidated nature of the material and the uniformity of the lithologies.

\subsection{Facies 1: Poorly sorted gravel and coarse sand, with some finer sand and mud}

Facies 1 consists mostly of lithofacies Gms, Gm and Gt of Miall (1977, 1978, 1984). It is characterised by discontinuous subhorizontal bedding with abundant channels and metre-scale cross-bedding (Fig. 17). The facies has a maximum thickness of about 20 to $30 \mathrm{~m}$. The sediments were deposited in three sub-environments: the braided rivers of the delta fan top; the shallow offshore section of the delta front; and the delta front beach. They comprise an estimated $10 \%$ of the total sediment volume.

The sediments and sedimentary structures are very variable. Most clasts are pebble and cobble size, with a matrix of granules and coarse sand. Gravels are both clast and matrix supported (Fig. 16) with alternations of coarser and finer beds. The material is poorly to very poorly sorted with little fine sand or mud. Clasts are moderately to well-rounded with a high sphericity and no obvious imbrication. Beds are 0.2 to $1.0 \mathrm{~m}$ thick, very discontinuous and cut by abundant channels. Cross-bedding has a 


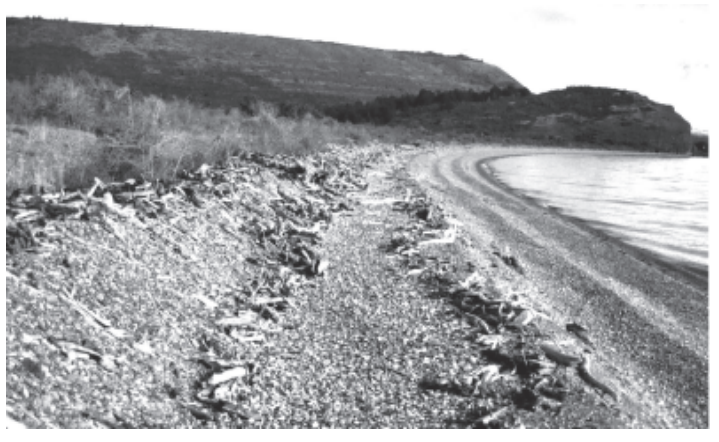

FIG. 15. Beach embayment with storm ridges. Rotten wood on the inner ridges indicates that wash-over ridges form during exceptional storms.

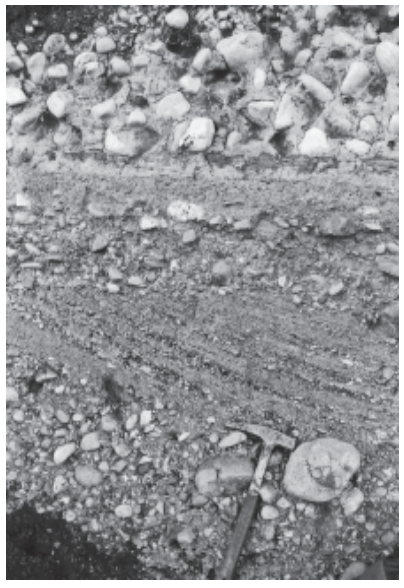

FIG. 17. Matrix and clast supported gravels of Facies 1 deposited in braided channels.

complex, tabular and irregular form, with variable orientation (Fig. 19). Drapes of fine sand blanket the gravels in small irregular channels (Fig. 18).

Facies 1 is a complex association representing a range of lithologies and sedimentary structures deposited by a complex interplay of processes in the three sub-environments. The present study was insufficiently detailed to differentiate the characteristic features of each sub-environment and to sub-divide the sediments into a more complex facies association. The materials, environments and processes comprise firstly fluvial material forming gravel sheets and lags in braided channels and bars, and as overbank flood splays produced by the traction and mass flow of rivers during flood events on the delta top. Secondly, an armoured lag of cobbles resulted from winnowing on gently sloping beaches backed by storm wash-over ridges. Thirdly, gravels

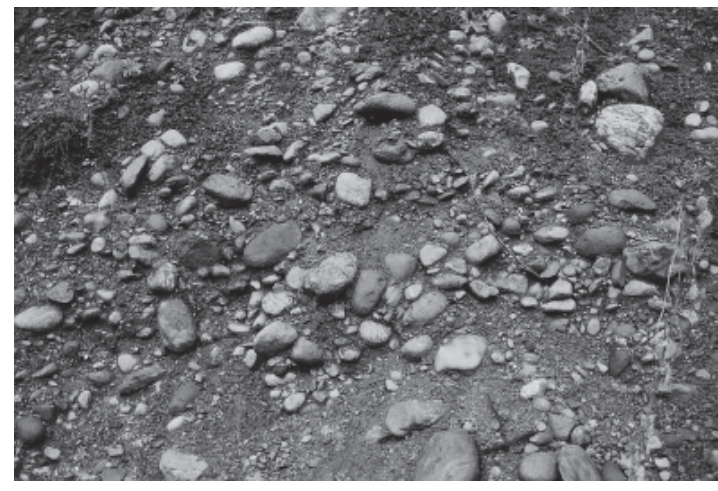

FIG. 16. Poorly-sorted matrix supported gravels of Facies 1.

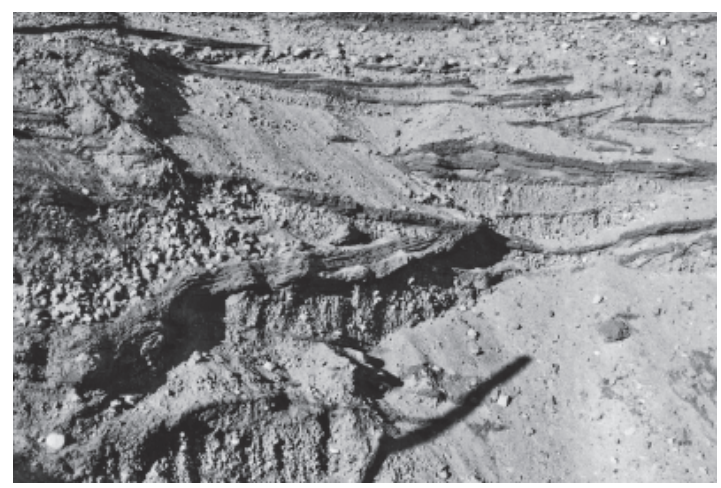

FIG. 18. Drapes of sand blanketing gravel in small irregular channels.

and sands of the shoreface platform were transported by strong lake-ward directed bottom currents during river flooding and the wave reworking of major storms (Rojas and Le Roux, 2005).

\subsection{Facies 2: Poorly sorted gravel and coarse sand with large-scale, steeply dipping pla- nar cross bedding}

Facies 2 forms units up to $100 \mathrm{~m}$ thick and it comprises about $60 \%$ of the total sediment volume. It has the same lithological characteristics as Facies 1. It is predominantly matrix supported and is characterised by steeply dipping (about $30^{\circ}$ ) foresets (Fig. 19). These foresets are straight and continuous for up to $10 \mathrm{~m}$ down slope. Poorly defined beds and laminations vary between 20 and $300 \mathrm{~mm}$ in thickness, with boundaries that merge into one another. 
Some beds fine upwards. No imbrication is apparent due to the spherical shape of the clasts.

\subsection{Facies 3: Well-sorted and rounded pebble and granule gravels}

Facies 3, comprising about $10 \%$ of the total volume of sediment, has very distinctive characteristics. Most of the material is very well-sorted and well to sub-rounded cobbles and pebbles with little sand (Fig. 20). The largest pebbles are $50 \mathrm{~mm}$ in diameter, with an average of about $20 \mathrm{~mm}$. Clasts have the same composition as those of Facies 1 and 2, although harder rock types (particularly vein quartz) are more abundant. The clast supported material is much better sorted and better rounded than that in Facies 1 and 2 . The bedding is diffusely stratified with poorly defined layers between 20 and $200 \mathrm{~mm}$ thick. Beds are sub-horizontal, parallel and continuous when viewed normal to the shoreline (Fig. 21) but are discontinuous, with tabular lake-ward dipping cross bedding, when viewed perpendicular to the shore.

\subsection{Facies 4: Organic-rich muddy sediments}

Organic-rich muddy sediments of Facies 4 form less than $1 \%$ of the total sediment volume. No outcrops were recorded in the abandoned deltas but swampy, muddy and densely vegetated areas occur behind the spit at the back of the beach embayment and in the inactive braided distributary tracts of the active delta fan (Fig. 13).

\section{Depositional Environments and processes}

The weather at the western end of Lake General Carrera is dominated by strong winds and heavy rainfall. The sediments are predominantly the product of the interplay of high rates of alluvial flow during flood events and storm-driven waves on the shores of the non-tidal lake. There is little sediment movement during normal river flow or fair weather and almost all sediment movement on the delta top occurs during floods. Coarse material is deposited in the river channels and bars and as overbank splays (Figs. 11 and 12) to form Facies 1. As water levels fall, sand is deposited in cut-off channels. A small amount of mud from overbank flooding settles from suspension to form Facies 4. Braided streams deposit some material on the delta

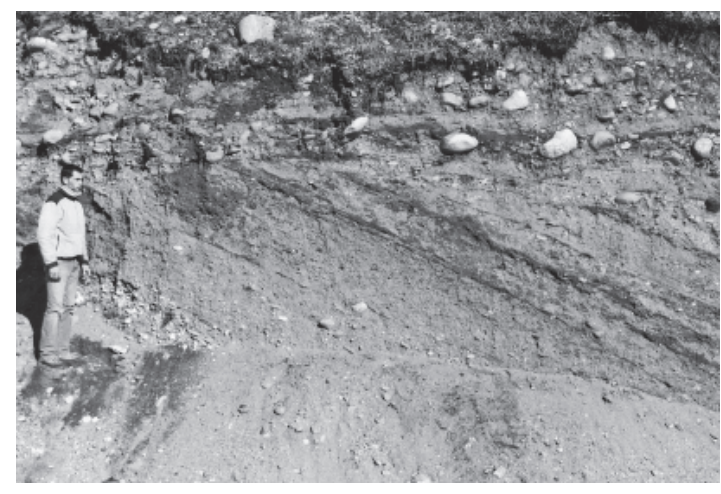

FIG. 19. Contact at the brink point between horizontally-bedded gravels of the delta top and steeply inclined foresets of the delta front slope.

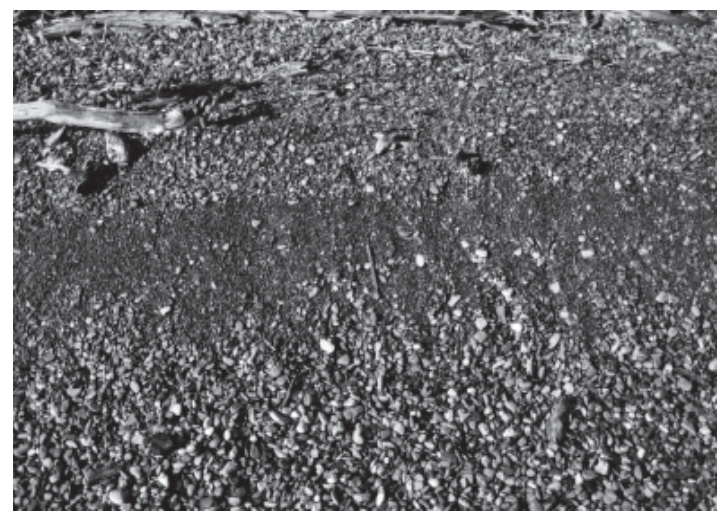

FIG. 20. Well-sorted and well-rounded beach gravels of Facies 3 in a beach embayment.

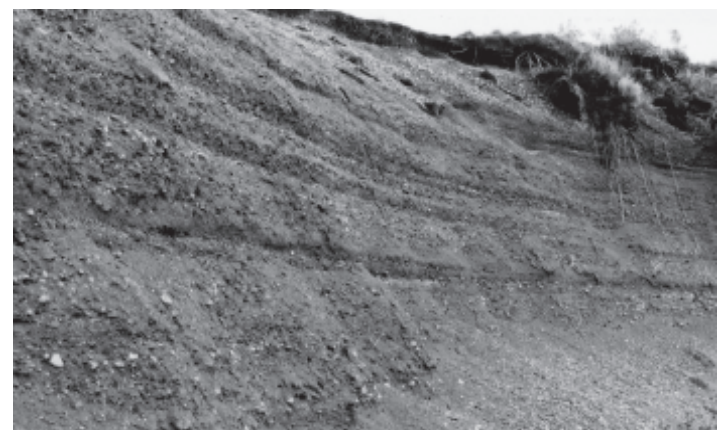

FIG. 21. Parallel-bedded beach gravels of the beach embayment viewed perpendicular to the shore.

top but most is transported across the delta to the lake margin (Bardaji et al., 1990). 
There is no data from the present study to indicate the processes operating on the shoreface platform offshore from the lake margin. However, a comparison with the studies of Rojas and Le Roux (2005) indicate that storm waves, together with lakeward-directed bottom currents enhanced by the effluent plume of the river, transport material to the brink point from where it cascades down the slope of the delta front into deeper water by mass flow avalanching. These Gilbert foresets of Facies 2 form at the angle of repose of the sediment (Fig. 10) (Nemec, 1990; Nemec et al., 1984; Nemec and Steel, 1984). Observations of the abandoned deltas on Lake General Carrera indicate that the surface of the delta front is relatively smooth with an absence of erosive channels or slump scars. This suggests that mass flow avalanching was in the form of a semi-continuous shower of material. As in the case in Lake Llanquihue, the activity of bivalves probably causes a cascade of sediment during normal weather conditions (Rojas and Le Roux, 2005). No fossils were found during the present study.

Waves transport gravel laterally from the delta front along the shoreline onto the beach embayments to deposit the gravels of Facies 3. Observations of clear, sediment-free water during the present study indicate that the sediment is only transported by breaking waves along the shore and not in deeper water during quiet weather and minor storms. During major storms material is thrown inland to form 1 to $2 \mathrm{~m}$ high wash-over ridges on both the fans and the beach embayments. In normal weather and small storms, the waves break on the beaches, but the larger waves of major storms break about $100 \mathrm{~m}$ offshore where they presumably transport sediment across the shoreface platform.

The southeastern shores of Lake General Carrera are oblique to the prevailing westerly winds and the beaches are dominated by wave processes. The fetch of about $20 \mathrm{~km}$ is sufficient to raise large waves (Massari and Parea, 1990; Renaut and Owen, 1991) which have a significant effect both on the morphology of the lakeshore and the characteristics of the beach sediments. All the material of the beach embayments (Figs. 15, 20 and 21) has been winnowed from the beaches of the delta fan and transported by long-shore drift driven by the impact of the oblique waves (Otvos, 2000). The larger area of the beach embayments east of the fans reflects the predominantly easterly transport of material. Wave action rounds and sorts the sediment, with winnowing action removing the finer material and producing the well-sorted gravels of Facies 3 (Bourgeois and Leithold, 1984; Wright and Coleman, 1973; Wright, 1978). As the finer gravel is transported away from the fan it leaves an armouring lag of tightly packed and well-sorted pebbles (Fig. 14).

The ridges at the back of the present-day beaches of the beach embayments (Fig. 15) are the product of storm wave action. The fronts of the ridges are blanketed with beech wood brought down by rivers in flood. The wooden branches on the inner section are rotten, suggesting, by comparison with the condition of wood used for house and fence-building in the area, an age of more than 50 years. This indicates that storms sufficiently large to produce the larger ridges are very rare events. The parallel systems of semi-continuous ridges on the plains behind the beach embayments (Fig. 8) provide a record of the progradation of the front of the embayment.

The effects of a major storm on a beach on Lake Llanquihue was recorded by Rojas and Le Roux (2005). Winds up $80 \mathrm{~km}$ per hour with a sustained speed of about $64 \mathrm{~km}$ per hour produced waves with a height of $2 \mathrm{~m}$, breaking about $40 \mathrm{~m}$ offshore, presumably at the brink point of the delta front. At the height of the storm $2 \mathrm{~m}$ of the coastline was eroded, with a $1 \mathrm{~m}$-wide storm beach formed parallel to the coast.

No pro-delta or bottom set sediments were recorded during the present study. Any fine material in suspension in the flooded rivers is carried offshore into deeper water as a sediment plume. Isolated occurrences of rhythmically laminated shales, interpreted as varves or annual cycles of sedimentation deposited in the proglacial lakes, are common at other locations in the region. They represent the eroded remnants of more extensive deposits (Sylwan, 1990; Sylwan and Beraza, 1990; Kaplan et al., 2004) deposited when the lakes were much larger than at present and, presumably, during a time when more abundant fine sediment was provided by the outwash of silty or muddy glacial rivers.

\section{Delta growth}

Variations in vegetation cover; climate related changes in precipitation; and episodes of glacial advance and retreat mean that the sediment flux has been very uneven. As a result of these changing factors the rate of growth of the deltas must have altered 
significantly over time. It is probable that, as the climate warmed and vegetation cover increased, the glacial and periglacial sediment supply decreased. In the early stages of the formation of each delta, rapid down-cutting of the unconsolidated sediment of the preceding delta produced abundant sediment and a fast growth rate. The growth rate would have slowed over time as the surface area expanded and the front of the delta lengthened. Growth also slowed significantly as the height of the foresets increased as the delta built out into deeper water.

It is probable that the deltas started forming about 13,000 years before the present and that delta number 2 had built out by about 8,500 years ago. Therefore deltas number 7 to number 2 formed over a period of about 5,000 years. By contrast the much smaller delta number 1 has formed since between 7,000 and 5,500 years ago. The small size of delta number 1 compared with deltas 2, 3 and 4 (Fig. 4) therefore indicates a significant slowing in the rate of formation.

It is estimated, on the basis of its size and age, that the presently active delta of the Las Dunas River is prograding slowly, at less than $0.2 \mathrm{~m}$ and possibly as little as $0.1 \mathrm{~m}$ per year. This is comparable to the $0.4 \mathrm{~m}$ per year determined for the Alta Delta of Norway (Corner et al., 1990).

\section{Conclusions}

Thick successions of gravel-dominated sediment form distinctive facies on lacustrine braid deltas in southern Chile. The deltas can be divided into two morphological components, the delta fan and the beach embayment, each with characteristic facies.

The deltas are the products of a high sediment influx onto a steep shoreline. As it built out into the lake the expanding fan developed a wedge shape, thickening into the deeper water. The sedimentary successions therefore wedge in the opposite direction from those of tectonically controlled basin margins where fan growth keeps pace with basin subsidence.

\section{Acknowledgements}

The encouragement and help of Dr. M. Suárez and R. De la Cruz of the Servicio Nacional Geología y Minería is gratefully acknowledged. L. Zúñiga provided enthusiastic field assistance. T. James produced the diagrams. The academic referees are thanked for their constructive criticism.

\section{References}

Bardaji, T.; Dabrio, C.J.; Goy, J.L.; Somoza, L.; Zazo, C. 1990. Pleistocene fan deltas in southeastern Iberian peninsula: sedimentary controls and sea-level changes. In Coarse-grained Deltas (Colella, A.; Prior, D.B.; editors). International Association Sedimentologists, Special Publication 10: 129-151. Oxford.

Bell, C.M. 2008. Punctuated drainage of an ice-dammed Quaternary lake in southern South America. Geografiska Annaler, Series A, Physical Geography 90A: 1-17.

Bell, C.M.; Suárez, M. 2000. The Río Lacteo Formation of Southern Chile. Late Paleozoic orogeny in the Andes of southernmost South America. Journal of South American Earth Sciences 13: 133-145.

Bornhold, D.B.; Prior, D.B. 1990. Morphology and sedimentary processes on the subaqueous Noeick River delta, British Columbia, Canada. In Coarse-grained Deltas (Colella, A.; Prior, D.B.; editors). International Association Sedimentologists, Special Publication 10: 169-181. Oxford.

Bourgeois, J.; Leithold, E.L. 1984. Wave-worked conglomerates-depositional processes and criteria for recognition. In Sedimentology of Gravels and Conglomerates (Koster, E.H.; Steel, R.J.; editors). Canadian Society of Petroleum Geologists, Memoir 10: 331-343.

Bowman, D. 1990. Climatically triggered Gilbert-type lacustrine fan deltas, the Dead Sea area, Israel. In Coarse-grained Deltas (Colella, A.; Prior, D.B.; editors). International Association Sedimentologists, Special Publication 10: 273-280-151. Oxford.

Clapperton, C.M. 1993. Quaternary geology and geomorphology of South America. Elsevier: 768 p. Amsterdam.

Corner, G.D.; Nordahl, E.; Munch-Ellingsen, K.; Robertson, K.R. 1990. Climatically triggered Gilberttype lacustrine fan deltas, the Dead Sea area, Israel. In Coarse-grained Deltas (Colella, A.; Prior, D.B.; editors). International Association Sedimentologists, Special Publication 10: 15-168. Oxford.

De la Cruz, R.; Suárez, M. 2006. Geología del Área Guadal-Puerto Sánchez, Región de Aisén del General Carlos Ibáñez del Campo. Servicio Nacional de Geología y Minería, Carta Geológica de Chile, Serie Geología Básica 95: 58 p.

Ethridge, F.G.; Wescott, W.A. 1984. Tectonic setting, recognition and hydrocarbon reservoir potential of fan-delta deposits. In Sedimentology of Gravels and Conglomerates (Koster, E.H.; Steel, R.J.; editors). Canadian Society of Petroleum Geologists, Memoir 10: 217-235.

Gilbert, G.K. 1890. Lake Bonneville. United States Geological Survey Monograph 1: 438 p. 
Gilli, A.; Anselmetti, F.S.; Ariztegui, D.; Beres, M.; McKenzie, J.A.; Markgraf, V.2005. Seismic stratigraphy, buried beach ridges and contourite drifts: the Late Quaternary history of the closed Lago Cardiel basin, Argentina (49 $\left.{ }^{\circ} \mathrm{S}\right)$. Sedimentology 52: 1-23.

Glasser, N.F.; Aniya, M.; Harrison, S.; Winchester, V. 2004. Late Pleistocene and Holocene palaeoclimate and glacier fluctuations in Patagonia. Global and Planetary Change 43: 79-101.

Hampton, B.A.; Horton,B.K. 2007. Sheetflow fluvial proceses in a rapidly subsiding basin, Altiplano plateau, Bolivia. Sedimentology 54: 1121-1148.

Horton, B.K.; Schmitt, J.G. 1996. Sedimentology of a lacustrine fan-delta system, Miocene Horse Camp Formation, Nevada, USA. Sedimentology 43: 133-155.

Heusser, C.J. 2003. Ice age southern Andes. A chronicle of palaeoecological events. Developments in Quaternary Science 3: 240 p. Elsevier, Amsterdam.

Hulton, N.; Sugden, D.; Payne, A.; Clapperton, C. 1994. Glacier modelling and the climate of Patagonia during the last glacial maximum. Quaternary Research 42: 1-19.

Kaplan, M.R.; Ackert, R.P.; Singer, B.S.; Douglass, D.C.; Kurz, M.D. 2004. Cosmogenic nuclide chronology of millennial scale glacial advances during O-isotope stage 2 in Patagonia. Geological Society America Bulletin 116: 308-321.

Kaplan, M.R.; Douglass, D.C.; Singer, B.S.; Ackert, R.P.; Caffee, M.W. 2005. Cosmogenic nuclide chronology of pre-last glacial maximum moraines at Lago Buenos Aires, $46^{\circ} \mathrm{S}$, Argentina. Quaternary Research 63: 301-315.

Klinger, Y.; Avouac, J.P.; Bourles, D.; Tisnerat, N. 2003. Alluvial deposition and lake-level fluctuations forced by Late Quaternary climate change: the Dead Sea case example. Sedimentary Geology 162: 119-139.

Lemons, D.R.; Chan, M.A. 1999. Facies architecture and sequence stratigraphy of fine-grained lacustrine deltas along the eastern margin of late Pleistocene Lake Bonneville, northern Utah and southern Idaho. American Association of Petroleum Geologists Bulletin 83: 635-665.

Massari, F.; Parea, G.C. 1990. Wave-dominated Gilbert-type gravel deltas in the hinterland of Taranto (Pleistocene, southern Italy). In Coarse-grained Deltas (Colella, A.; Prior, D.B.; editors). International Association Sedimentologists, Special Publication 10: 311-331. Oxford.

McPherson, J.G., Shanmugam, G.; Moiola, R.J. 1987. Fan-deltas and braid deltas: varieties of coarse-grained deltas. Bulletin Geological Society America 99: 331-340.

McPherson, J.G.; Shanmugam, G.; Moiola, R.J. 1988. Fan deltas and braid deltas: conceptual problems. In Fan Deltas Sedimentology and Tectonic Setting (Nemec, W.; Steel, R.J.; editors). Blackie and Son Ltd.: 15-22.
Miall, A.D. 1977. A review of the braided river depositional environment. Earth Science Reviews 13: $1-62$.

Miall, A.D. 1978. Lithofacies types and vertical profile models of braided river deposits, a summary. In Fluvial Sedimentology (Miall, A.D.; editor). Memoir Canadian Society Petroleum Geologists 5: 597-604.

Miall, A.D. 1984. Principles of Sedimentary Basin Analysis. Springer Verlag: 490 p. New York.

Nemec, W. 1990. Aspects of sediment movement on steep delta slopes. In Coarse-grained Deltas (Colella, A.; Prior, D.B.; editors). International Association Sedimentologists, Special Publication 10: 29-73. Oxford.

Nemec, W.; Steel, R.J. 1984. Alluvial and coastal conglomerates: their significant features and some comments on gravelly mass-flow deposits. In Sedimentology of Gravels and Conglomerates (Koster, E.H.; Steel, R.J.; editors), Canadian Society of Petroleum Geologists, Memoir 10: 1-31.

Nemec, W.; Steel, R.J. 1988. Fan Deltas: sedimentology and tectonic settings. Blackie: 444 p. Glasgow.

Nemec, W.; Steel, R.J.; Porębski, S.J.; Spinnangr, Å. 1984. Domba conglomerate, Devonian, Norway: processes and lateral variability in a mass flow-dominated, lacustrine fan-delta. In Sedimentology of Gravels and Conglomerates (Koster, E.H.; Steel, R.J.; editors). Canadian Society of Petroleum Geologists, Memoir 10: 295-320.

Niemeyer, H.; Skarmeta, J.; Fuenzalida, R.; Espinosa, W. 1984. Hojas Península de Taitao y Puerto Aysén, Región de Aysén del General Carlos Ibáñez del Campo. Carta Geológica de Chile 60-61: 80 p.

Otvos, E.G. 2000. Beach ridges-definitions and significance. Geomorphology 32: 83-108.

Oviatt, C.G.; McCoy, W.D.; Nash, W.P. 1994. Sequence stratigraphy of lacustrine deposits: a Quaternary example from the Bonneville basin, Utah. Geological Society of America, Bulletin 106: 133-144.

Postma, G. 1990. Depositional architecture and facies of river and fan deltas: a synthesis. In Coarse-grained Deltas (Colella, A.; Prior, D.B.; editors). International Association Sedimentologists, Special Publication, 10: 13-27. Oxford.

Renaut, R.W.; Owen, R.B. 1991. Shore-zone sedimentation and facies in a closed rift lake: the Holocene beach deposits of Lake Bogoria, Kenya. Special Publication International Association Sedimentologists 13: 175-195.

Ricketts, B.D.; Evenchick, C.A. 2007. Evidence of different contractional styles along foredeep margins provided by Gilbert deltas, examples from Bowser Basin, British Columbia, Canada. Bulletin Canadian Petroleum Geology 55: 243-261.

Rojas, E.; Le Roux, J. 2005. Sedimentary processes on a Gilbert-type delta in Lake Llanquihue, southern Chile. Revista Geológica de Chile 32 (1): 19-31. 
Sylwan, C.A. 1990. Paleomagnetism of glacial varves from the last glaciation maximum in Patagonia at Lago Blanco. Physics of the Earth and Planetary Interiors 64: 143-152.

Sylwan, C.A.; Beraza, L.A. 1990. Paleomagnetic record from glacial varves in Alto Río Mayo, Patagonia, Argentina. Physics of the Earth and Planetary Interiors 61: 230-237.

Manuscript received: November 20, 2007; accepted: May 20, 2008.
Wright, L.D. 1978. River deltas. In Coastal Sedimentary Environments (Davies, R.A.; editor). Springer-Verlag: 5-68.

Wright, L.D.; Coleman, J.M. 1973. Variations in morphology of major river deltas as functions of ocean wave and river discharge regimes. American Association Petroleum Geologists Bulletin 57: 370-398. 